\title{
O Peso da Redemocratização no Processo de Integração entre Brasil e Argentina
}

\author{
Fabricio R. Marques ${ }^{(*)}$ \\ Luis Rodolfo Cruz e Creuz \\ Marcelo Driusso ${ }^{(*+*)}$
}

\begin{abstract}
Resumo: O objetivo deste estudo é realizar uma revisão do marco histórico e explorar o impacto do encerramento das ditaduras militares no Brasil e na Argentina, em meados dos anos 1980, no processo de integração entre os dois países. Após décadas de rivalidade, interna e externa, em que ambos os vizinhos consolidaram a crença de que a ameaça morava ao lado, os acordos celebrados entre os presidentes José Sarney e Raul Alfonsín sinalizaram, a partir de 1985, um novo momento na relação bilateral e regional, ao estabelecer, primeiramente, uma aproximação na delicada política nuclear, um dos focos principais da histórica desconfiança. Essa etapa abriu caminho também para uma forte aproximação na esfera econômica. O Programa de Integração e Cooperação Econômica, instituído em 1986, anunciou de modo explícito o propósito de instituir um "espaço econômico comum” em que setores da economia dos dois países se complementariam. A percepção crescente de que ambos tinham muito a ganhar com o processo de integração ajudou a pavimentar a criação em 1991 do Mercado Comum do Sul (Mercosul), que reuniria também o Paraguai e o Uruguai. Tais acordos de integração, não por acaso, tinham como preocupação dos países signatários do Mercosul o compromisso de que fossem preservadas suas instituições democráticas.
\end{abstract}

Palavras-chave: Integração Regional, Redemocratização, Brasil e Argentina, Mercosul.

(*) Jornalista formado na Universidade de Brasília (UnB). Editor executivo de Política Científica e Tecnológica da revista Pesquisa FAPESP e professor do curso de jornalismo das Faculdades de Campinas (FACAMP). Mestre pelo Programa de Pós-Graduação em Integração da América Latina da Universidade de São Paulo (PROLAM/USP). E-mail:<frmarques@gmail.com>.

(**) Advogado e Consultor em São Paulo. Sócio de Creuz e Villarreal Advogados. Bacharel em Direito pela Pontifícia Universidade Católica de São Paulo — PUC/SP, pós-graduado em Direito Societário, no curso LLM Master of Laws, do IBMEC São Paulo; Mestre em Relações Internacionais pelo Programa Santiago Dantas, do convênio das Universidades UNESP/UNICAMP/PUC-SP; e Mestre pelo Programa de Pós-Graduação em Integração da América Latina da Universidade de São Paulo - USP. Autor da monografia "Commercial and Economic Law — Brasil” da International Encyclopedia of Laws, editada por Dr. Jules Stuyck. Holanda: Kluwer Law International, 2010 (ISBN 978-90-654-4942-9). Autor do livro Acordo de Quotistas - Análise do instituto do Acordo de Acionistas previsto na Lei n. 6.404/1976 e sua aplicabilidade nas Sociedades Limitadas à Luz do Novo Código Civil brasileiro, com contribuições da Teoria dos Jogos. São Paulo: IOB-Thomson, 2007. E-mail: <lrcreuz@usp.br.>

(***) Administrador e Consultor de Empresas em São Paulo. Bacharel em Administração pela Pontifícia Universidade Católica de São Paulo - PUC/SP. Mestre pelo Programa de Pós-Graduação em Integração da América Latina da Universidade de São Paulo _ USP. E-mail:mdriusso@uol.com.br. Recebido em 2.2.2010 e aceito em 22.3.2010. 


\begin{abstract}
The objective of this study is a revision of a historic landmark and explore the impact of the end of the dictatorships in Brazil and Argentina, in the 1980s, during the process of integration of these two countries. After decades of rivalry, internal and external, where those neighbors strengthened the belief that the threaten lived next door, agreements between presidents José Sarney and Raul Alfonsín, signalized, since 1985, a new momentum in the bilateral and regional relationship, establishing, in the first place, an approximation of the delicate nuclear politics, one of the main focus of the historical suspiciousness. This step has opened ground for strong economic approximation. The program of Integration and Economic Cooperation, established in 1986, explicit the purpose of constitute a "common economic space" in which sectors of the economy of both countries would complement mutually. The growing perception that both had a lot to win in the integration process helped to concrete, in 1991, the creation of South Common Market (MERCOSUL), that would gather also Paraguay and Uruguay. Such integration agreements, not by chance, had the concern of the signatory countries of Mercosul the commitment to preserve its democratic institutions.
\end{abstract}

Keywords: Regional Integration, Redemocratization, Brazil and Argentina, Mercosul. 


\section{INTRODUÇÃ̃o ${ }^{(1)}$}

Regimes autoritários têm dificuldade inata de patrocinar processos de integração regional ou de participar deles. A incompatibilidade tem razões variadas. Com a multiplicação de práticas econômicas e de responsabilidades compartilhadas, a integração impõe processos de transferência de soberania política que, a despeito das vantagens prometidas, não encontram intersecção possível com os ideários nacionalistas frequentemente seguidos por ditaduras tampouco pela tendência desses regimes de buscar hegemonia e fomentar disputas geopolíticas com vizinhos. Outro complicador é que os regimes de exceção inspiram uma natural desconfiança em negociações multilaterais. Se não existem referências legais consolidadas ou sistemas jurídicos transparentes a regular o cotidiano de um país, que garantias os vizinhos e os investidores terão em relação ao respeito de seus direitos?

Chiarelli (1997) sustenta que a liberdade de empreender, característica das democracias liberais, representa requisito fundamental na promoção da integração. Já o dirigismo estatal e as limitações à livre circulação de pessoas, que ocorrem com frequência em ditaduras, são em geral incompatíveis com a concepção de blocos econômicos:

A estatização, a economia dirigida, o sistema oficial de subsídios, desequilibrando o processo concorrencial, inviabilizando o livre mercado, são procedimentos, no mundo econômico, que afrontam com a ideia de Integração, necessariamente casada com a livre-iniciativa, a ausência de incentivos governamentais, a circulação extrafronteiras de pessoas e capitais, etc. A integração tem sua base econômica assentada na melhor produtividade para garantir exitosa competitividade. É a vitória do mais apto, e não do mais protegido (CHIARELLI, 1997, p. 20).

A Comunidade Europeia do Carvão e do Aço (Ceca), fundada em 1951 e considerada o primeiro passo concreto para a integração da porção ocidental do Velho Continente, só se tornou viável após a consolidação da democracia em países que haviam vivido regimes totalitários poucos anos antes, notadamente a Itália e a Alemanha (VALENTINI, 2007). Foi a primeira vez que ocorreu transferência de direitos de soberania de alguns países para uma instituição europeia. O objetivo da Ceca, formada por França, Itália, Alemanha Ocidental, Holanda, Bélgica e Luxemburgo era integrar as indústrias do carvão e do aço dos países europeus ocidentais.

Criada em 1957, a Comunidade Econômica Europeia (CEE), composta, não por acaso, pelos mesmos países da Ceca, não exigia formalmente em seus primórdios que seus membros fossem democracias. Mas o ingresso de nações como Portugal, Grécia e Espanha só foi possível em meados dos anos 1980, algum tempo após o encerramento de seus ciclos autoritários. Aqui, verificamos forte corelação com o tema a que nos propusemos, considerando o visível inter-relacionamento entre os tempos de paz e ventos

(1) O presente artigo teve origem no trabalho apresentado por Fabrício R. Marques, Luís Rodolfo Cruz e Creuz e Marcelo Driusso, no primeiro semestre de 2008 na disciplina "Integração Econômica Regional”, ministrada pelo prof. Dr. Márcio Bobik Braga, no curso de pós-graduação (mestrado) do Programa de Pós-Graduação em Integração da América Latina da Universidade de São Paulo — PROLAM/USP. 
democráticos, e períodos obscuros com marcada influência autoritária. Desta feita, com a queda das ditaduras militares em Portugal (1974), Grécia (1974) e Espanha (1975) foi propiciada a adesão destes países à CEE. Em 1981, a Grécia, Espanha e Portugal, em 1986, tornaram-se membros da comunidade, passando esta a estender-se até a Europa mediterrânica.

Em 1962, os três países chegaram a manifestar a intenção de aderir ao bloco. O processo de adesão da Grécia ficou suspenso ao longo da ditadura que vigorou de 1967 e 1974. Portugal só trabalhou efetivamente pela adesão a partir de 1977, três anos após a Revolução dos Cravos, que sepultou a ditadura nacionalista e isolacionista inaugurada em 1932 por António de Oliveira Salazar (1889-1970). A Espanha igualmente candidatou-se a ingressar no bloco após a morte do Generalíssimo Francisco Franco (1892-1975). As disparidades econômicas existentes nestes países, somadas à má reputação que seus regimes tinham entre a opinião pública europeia, exigiam uma boa vontade nas negociações que nem seus ditadores nem as autoridades do bloco se dispuseram a empreender.

A experiência da América Latina também mostra que a instabilidade política impôs obstáculos a pelo menos dois esforços de integração empreendidos a partir dos anos 1960. O Mercado Comum Centro-Americano (MCCA), que reúne Costa Rica, Guatemala, Honduras, Nicarágua e El Salvador, obteve resultados animadores em seus primórdios, até que alguns de seus países-membros, tomados por perturbações políticas, converteram-se em adversários. Em 1969, os vizinhos Honduras e El Salvador, governados respectivamente pelos generais-presidentes Oswaldo López Arellano e Fidel Sánchez Hernández, mantiveram uma guerra por questões fronteiriças. Após o fim do conflito, que durou 100 horas, Honduras fechou a passagem pelo seu território dos caminhões salvadorenhos, causando um duro golpe nas relações comerciais entre os países centro-americanos.

Da mesma forma, o Pacto Andino, hoje formado pela Bolívia, Colômbia, Equador e Peru e Venezuela, sofreu um revés importante em 1976, com a saída do Chile do bloco. Em 1978, a Bolívia rompeu relações com o Chile, que, em ato seguinte, retirou-se do bloco. O Chile foi membro oficial do Pacto Andino entre os anos de 1969 a 1976, permanecendo como observador de 1976 a 2006. Em 24 de novembro de 2006, o Chile tornou-se membro associado do Pacto, quando foi assinada a "Ata de Constituição da Comissão Mista entre a Comunidade Andina e o Chile", que representou importante avanço e para o retorno do Chile ao bloco, sendo que na mesma Ata, foi criado um grupo de trabalho visando refletir sobre as possíveis formas de representantes chilenos integrarem os órgãos internos do bloco.

A interrupção do processo de integração foi um efeito do golpe militar ocorrido no Chile, que derrubou o presidente eleito democraticamente Salvador Allende três anos antes, como lembra Santoro (2005):

O general Pinochet foi um aliado fiel nos combates da Guerra Fria, chegando mesmo a retirar seu país do Pacto Andino, cujos projetos autonomistas eram vistos com reservas por Washington. Porém, naquele período o Chile continuou bastante 
integrado a seus vizinhos latino-americanos, em particular na repressão internacional contra a esquerda, a chamada Operação Condor. As relações com a Argentina se deterioraram rapidamente, por conta das disputas fronteiriças no Canal de Beagle (SANTORO, 2005, p. 5).

Nascido sob o signo da redemocratização de seus países-membros, o Mercado Comum do Sul (Mercosul) é citado como exemplo da importância da estabilidade política na sobrevivência de um bloco econômico. Interessante destacar o acompanhamento dos processos globais de busca de mercados e, com certeza, sob grande impacto do fenômeno da globalização, sendo o processo de integração, no caso do Mercosul, utilizado como alavanca para o processo de desenvolvimento, há muito influenciado pelo pensamento e trabalho da Comissão Econômica para a América Latina e Caribe (CEPAL), que fortemente defendia a industrialização da América Latina. Contudo, Braga (2002) destaca problemas de coordenação nas décadas de 70 e 80 como elementos de fracasso do modelo cepalino de desenvolvimento. Por outro lado, os governos buscaram, na década de 90, valer-se dos fundamentos macroeconômicos para fixar políticas de estabilização, fortemente influenciadas pelos processos de redemocratização. Segundo Vigevani e Veiga (1996):

Os governos, sobretudo a partir de 1991, utilizaram a integração como uma alavanca para a sustentação da política de estabilização macroeconômica. Mesmo na fase anterior ao Tratado de Assunção, no período Alfonsín-Sarney (1986-1989), em alguma medida o objetivo dos governos era o de utilizar a integração regional para a modernização, ainda que sem privilegiar a abertura comercial para o mundo, concentrando-se nas possibilidades oferecidas por um mercado interno mais amplo (VIGEVANI; VEIGA, 1996, p. 232).

Em 1996, um golpe de Estado foi abortado no Paraguai graças à mobilização de diplomatas e autoridades dos demais parceiros, Brasil, Argentina e Uruguai, alertando os militares paraguaios sobre a inevitável exclusão do país do bloco em caso de rompimento institucional. Fernández (1997), referindo-se ao episódio, afirma que as relações políticas forjadas em regiões integradas economicamente ajudam a estreitar os laços entre os países-membros, como também promover a troca de informações entre vizinhos democráticos e prevenir conflitos entre os membros mais afoitos e belicosos. Após o episódio paraguaio, foi pactuada em 24 de julho de 1998 a chamada cláusula democrática do Mercosul. O Protocolo de Ushuaia, assinado por Brasil, Argentina, Paraguai e Uruguai, além da Bolívia e do Chile, membros associados, estabeleceu formalmente que a vigência das instituições democráticas é condição sine que non para o desenvolvimento da integração regional, sob pena de exclusão dos infratores do bloco. É interessante, ainda, destacar que a sistemática utilizada pelo Protocolo de Ushuaia implica, nos termos do seu art. $4^{\circ}$ que, "no caso de ruptura da ordem democrática em um Estado-Parte do presente Protocolo, os demais Estados-Partes promoverão as consultas pertinentes entre si e com o Estado afetado". Sendo que o art. $5^{\underline{o}}$ seguinte fixa momento seguinte na hipótese de fracasso nesta primeira tentativa, a saber: "Quando as consultas mencionadas no artigo anterior resultarem infrutíferas, os demais Estados-Partes do presente Protocolo, 
no âmbito específico dos Acordos de Integração vigentes entre eles, considerarão a natureza e o alcance das medidas a serem aplicadas, levando em conta a gravidade da situação existente. Tais medidas compreenderão desde a suspensão do direito de participar nos diferentes órgãos dos respectivos processos de integração até a suspensão dos direitos e obrigações resultantes destes processos”.

\section{As TENTATIVAS DE INTEGRAÇÃo}

Ideias integracionistas animam os países latino-americanos desde seus processos de independência. Simon Bolívar (1783-1830) acalentava o sonho de reunir a América espanhola numa só nação confederada. O grande argumento regional está lastreado na tentativa de alcançar a união política para superar a dependência econômica. Em 1938, o político argentino Alejandro Bunge propôs formalmente a criação de uma União Aduaneira do Sul, reiterada quatro anos mais tarde na Conferência dos países de La Plata (MAGARIÑOS, 2005).

As primeiras experiências efetivas de integração da América Latina remontam ao início dos anos 1950, a partir dos diagnósticos feitos pela Comissão Econômica para a América Latina e o Caribe (CEPAL) segundo os quais o crescimento dos países do continente esbarrava numa limitação importante, a exiguidade de seus mercados, e a necessária industrialização da região poderia ser potencializada por uma estratégia integracionista. A criação nos anos 1960 da ALALC (Associação Latino-Americana de Livre Comércio - sucedida em 1980 pela ALADI (Associação Latino-Americana de Desenvolvimento), tentativa de unir numa área de livre-comércio a Argentina, o Brasil, o Chile, o México, o Paraguai, o Peru e o Uruguai; do MCCA (Mercado Comum Centro-Americano), que reúne Costa Rica, Guatemala, Honduras, Nicarágua e El Salvador; e do Pacto Andino, formado pela Bolívia, Colômbia, Equador e Peru e Venezuela, encarnaram, sob a influência da CEPAL, a ideia de que as economias latino-americanas poderiam ganhar dinamismo com a constituição de mercados expandidos, a exemplo da bem-sucedida experiência do Mercado Comum Europeu, nascido nos anos 1950. Importante destacar, ainda, outros antecedentes importantes nas relações internacionais dos países latino-americanos, como por exemplo, o Tratado da Bacia do Prata, de 1969, o Tratado firmado em 1973, com o governo do Paraguai, que resultou na construção da hidrelétrica de Itaipu, seguido, em 1979, pelo acordo entre Argentina, Paraguai e Brasil, visando o compartilhamento das usinas hidrelétricas de Itaipu e Corpus, e o Tratado de Cooperação da Amazônia, firmado em 1978, dentre outros importantes marcos diplomáticos e estratégicos que remontam à década de 30 (LAFER, 2001, p. 58).

Não obstante estas construções, podemos indicar o governo do presidente Juscelino Kubitschek como um marco de uma nova fase de relacionamento entre os países da América Latina. Segundo Bueno (2004):

O presidente brasileiro deu ênfase à aproximação da Argentina, Bolívia e Paraguai. A Operação Pan-Americana (OPA) por ele lançada em 1958 teve uma abrangência 
latino-americana. Tanto é assim que um dos resultados visíveis da OPA foi a criação da Associação Latino-Americana de Livre Comércio (ALALC), pelo Tratado de Montevidéu de 1960. Jânio Quadros deu continuidade à política de aproximação com a nação platina e firmou com o presidente Arturo Frondizi o Acordo de Amizade e Consulta, bem como duas declarações (uma econômica e outra política) em Uruguaiana, Rio Grande do Sul, em abril de 1961. Neste mesmo ano, começou a se reunir o Grupo Misto de Cooperação Industrial Brasil-Argentina, que fora criado em 19 de setembro de 1958, ainda na gestão JK (BUENO, 2004, p. 72).

Dos estudos seminais da CEPAL, entre 1956 e 1957, a cooperação econômica adquiriu status de força motriz da aceleração do crescimento econômico da América Latina. Nesta esteira, o movimento integracionista da América Latina tem sua gênese na Conferência da CEPAL no Panamá (1959), quando foram colocadas propostas de estabelecimento de um mercado comum na região. Segundo Araújo (2008), dentre as propostas, destacam-se:

(i) adesão ao mercado regional, aberta a todos os países latino-americanos; (ii) inclusão de todos os itens produzidos nos países da região como finalidade do mercado regional; (iii) tratamento especial conferido aos países menos desenvolvidos; (iv) sistema especial de pagamentos multilaterais, a fim de maximizar a reciprocidade de intercâmbio intrarregional; (v) fomento de acordos de complementação e especialização entre países vinculados pela proximidade geográfica ou por interesses econômicos comuns; e (vi) coordenação da política comercial e o estabelecimento de uma tarifa externa comum em relação a terceiros países (ARAÚJO, 2008, p. 117).

O pensamento cepalino, que segundo Márcio Bobik Braga, não encontra forte eco na literatura econômica sobre economia internacional, apresenta forte contribuição ao processo de integração. Braga (2002, p. 11) ressalta duas fases do pensamento cepalino voltado para a integração regional da América Latina. A primeira foi direcionada para a integração regional enquanto instrumento de desenvolvimento econômico, sendo que as suas ações neste sentido acabaram por não prosperar da forma como idealizadas. A segunda fase, já nos anos 1990, por força do processo de globalização, baseou-se na utilização da integração regional como força motriz da busca de uma maior inserção das economias latino-americanas na economia internacional. Segundo Braga, estas ideologias da CEPAL:

demonstram, por exemplo, a importância da integração econômica regional para o desenvolvimento orientado pelo processo de substituição de importações e também para a formulação de estratégia visando uma maior inserção da América Latina nas relações econômicas internacionais. Destacam ainda os fatores que têm dificultado este processo de integração, principalmente no que diz respeito à coordenação das políticas macroeconômicas entre os países envolvidos (BRAGA, 2002, p. 11).

A trajetória da ALALC expôs as dificuldades de integrar economias com níveis diferentes de industrialização e perfil exportador semelhante num continente, bem ao contrário do que ocorria na Europa, marcado por fortes desigualdades sociais. A 
ocorrência de desequilíbrios comerciais, a impossibilidade de manter saldos deficitários e as disputas entre interesses nacionais e setoriais fizeram com que o marco da ALALC, o Tratado de Montevidéu, revelasse sinais de inviabilidade já nas primeiras rodadas de negociação. O referido tratado, assinado em 1960, previa que os países-membros deveriam eliminar "todos os direitos aduaneiros e quaisquer outros encargos de efeitos equivalentes que incidissem sobre as importações” num prazo de 12 anos. As dificuldades de aprovar listas nacionais de mercadorias (com reduções tarifárias propostas anualmente por cada país) e listas comuns de produtos (com concessões irrevogáveis negociadas a cada três anos), cujo objetivo era gradualmente liberalizar o comércio na região, fizeram com que o prazo para a integração fosse prorrogado até 1980. Na prática, a ALALC perdeu sua eficácia pouco depois de nascer. Do total de 11.173 concessões acumuladas até 1977, mais de dois terços corresponderam ao período 1962/1964 e mais de 80\% aos anos 1962/1966 (VERSIANI, 1986). A ideia de criar uma área de livre comércio deu espaço a uma iniciativa bem mais tímida, com a criação de uma zona de preferências tarifárias.

Há consenso de que o fracasso da ALALC se deveu a uma combinação de fatores. Um deles foi o rigor excessivo dos instrumentos previstos no Tratado de Montevidéu, como a cláusula da nação mais favorecida (NMF), que estendia a todos os países-membros qualquer vantagem estabelecida em negociações bilaterais. Conforme Versiani (1986), outro problema era a dificuldade, por parte dos países mais adiantados da área, em aceitar uma redução no nível de atividade de um de seus setores produtivos:

Se quem faz uma concessão, ou sofre uma perda, não se julga mais compensado por um benefício, então não se sentirá induzido a participar do processo de integração. Ou seja: ainda admitindo a hipótese de que a supressão de tarifas na região seja potencialmente benéfica para todos, isso no entanto não basta. É preciso que todos os participantes tenham, de fato, ganhos líquidos (ou, pelo menos, não tenham perdas). Caso contrário, fatalmente se chegará a um impasse (VERSIANI, 1986, p. 34).

Hernandes (2004) destaca outra dificuldade: a proliferação de regimes ditatoriais na América Latina, que, na contramão da proposta cepalina de integrar as economias para alavancar a industrialização, adotaram um protecionismo fechado:

O fracasso decorreu de diversos fatores, entre eles, as crises estruturais dos diferentes países da América Latina que dificultaram a integração. Tais crises decorrem dos regimes ditatoriais dominantes na maioria dos países da América Latina, a partir da década de 60, que fez com que os países se fechassem a um nacionalismo extremo, ao seguir o modelo de substituição das importações por industrialização crescente, que ocasionou o enfraquecimento da integração. Outro fator chave para entender o fracasso da ALALC foi a previsão da "cláusula da NMF" sem a possibilidade de nenhuma exceção. Observe-se que o modelo previsto no Tratado de Montevidéu, que visava a alcançar o estágio de Mercado Comum por meio de uma Área de Livre Comércio, era muito rigoroso e distante da realidade latino-americana, pois como as negociações eram multilaterais, não se observava as diversidades dos seus Membros (HERNANDES, 2004). 
O embaixador Samuel Guimarães (2007) complementa o quadro lembrando que:

a integração encontrou obstáculos causados pelas políticas nacionais de substituição de importações e de industrialização e, mais tarde, pelas políticas de controle de importações para enfrentar as súbitas crises do petróleo que acarretaram inéditos déficits comerciais que atingiram os países importadores de energia, em especial o Brasil.

A rivalidade causada pelos regimes militares acabou por afastar os países, que até o momento, vinham sinalizando fortes movimentos de derrubada de barreiras políticas e econômicas, com vista a fomentar o processo de integração. Bueno (2004) destaca:

Durante os períodos militares dos dois países, houve um novo surto de rivalidade, especialmente em razão do contencioso que se estabeleceu em torno do aproveitamento dos recursos hídricos do Rio Paraná. O Brasil teve, por conta disso, problemas na esfera multilateral, especialmente na Conferência Mundial do Meio Ambiente de Estocolmo, em 1972, quando a Argentina defendeu a tese da consulta prévia e das informações técnicas que um país deveria prestar a outro no caso de aproveitamento de recursos naturais compartilhados (BUENO, 2004, p. 73).

Camargo (1989) cita o fato de a integração nos anos 1960 e 1970 ter sido comandada por técnicos e representantes governamentais, com baixa adesão de representantes setoriais, o que explica as dificuldades. O autor ainda lembra que processos de integração, com a multiplicação de práticas econômicas e de responsabilidades compartilhadas, conduzem a um processo de transferências de soberanias políticas e, como decorrência, ao estabelecimento de um poder supranacional:

A constituição de um poder de decisão acima das soberanias nacionais é uma tarefa a bastante longo prazo, com todas as possibilidades de ser abortada no meio do caminho. O próprio processo de formação de uma comunidade europeia demonstra a dificuldade em se encontrar um modelo que, levando-se em conta a história desse continente, caracterizado por lutas hegemônicas entre seus Estados e guerras cruentas, fosse capaz de criar mecanismos integrativos que implicassem cessão de soberania às entidades centrais das organizações multilaterais (CAMARGO, 1989, p. 48$)$.

Em 1980, prazo fatal para a formação da área de livre comércio, a ALALC foi sepultada oficialmente com a assinatura do segundo Tratado de Montevidéu, que criou a ALADI (Associação Latino-Americana de Integração). Tendo como países-membros Argentina, Bolívia, Brasil, Chile, Colômbia, Cuba, Equador, México, Paraguai, Peru, Uruguai e Venezuela, a ALADI previa mecanismos de integração mais flexíveis, abrindo espaço para o caráter bilateral que marcava as práticas comerciais anteriores ao esforço integracionista.

Os anos 1980, porém, trariam novos dilemas para as economias latino-americanas. Se durante as décadas de 1950 a 1980 elas conseguiram expandir-se, notadamente nos 
anos de 1970 em decorrência da oferta abundante de crédito e do dinamismo dos grandes centros industriais, a chamada "década perdida" foi marcada pela crise da dívida, pela estagnação e pela escalada da inflação.

As questões econômicas e a situação dos países na América Latina influenciavam igualmente as ações e opções dos mesmos, tendo em vista a necessidade de manejo interno e coordenação internacional, por causa dos fortes sinais já inicialmente percebidos decorrentes dos processos de globalização. Aqui, imperioso destacar o contexto histórico econômico vivenciado especialmente por Brasil e Argentina. Segundo Braga (2002):

a partir dos anos 70 e principalmente durante os 80, diversos países latino-americanos, a exemplo da Argentina e Brasil, experimentaram fortes instabilidades macroeconômicas caracterizadas por processos inflacionários crônicos, inconsistências intertemporais nos processos de endividamento interno e principalmente externo (pelo menos num primeiro momento). Ainda que as altas taxas de inflação tenham sido contidas nos anos 90, verificam-se nesta década grandes instabilidades cambiais e forte vulnerabilidade externa dos países da região. Num processo de baixa integração, estes fatores não têm tanta importância dada a reduzida possibilidade de transmissão das instabilidades entre os países. Entretanto, com o avanço da integração, seria fundamental algum tipo de coordenação macroeconômica, uma vez que as transmissões das instabilidades macroeconômicas entre os países seriam intensas (BRAGA, 2002, p. 20-21).

Como mostra Camargo (1989), em decorrência da crise, o grau de industrialização de alguns países, como Argentina, Peru, Chile e Uruguai, caiu em 1983 no nível de 1960. A partir de 1984, a indústria iniciou uma recuperação, mas o produto industrial da região, excetuando-se o Brasil, ainda permaneceu $7 \%$ mais baixo do que o nível alcançado em 1980. Sem ter influência sobre os desdobramentos da crise internacional, os países latino-americanos não tiveram outra opção além de retirar do limbo o debate sobre a integração regional.

\section{Brasil-Argentina, da Rivalidade À INTEgRaçÃo}

Fixar marcos históricos e contextuais do processo de integração remontam ao período colonial das Américas. Neste sentido, é imperioso recordar as influências, na América Latina, das formas e métodos de colonização, tendo em vista o fluxo existente, para o Brasil especificamente de Portugal, e da Espanha, para as suas colônias na América. Tal processo, em virtude da rivalidade e competição existentes nas metrópoles, acabava por apresentar seus reflexos e influências do outro lado do Atlântico. Nas palavras de Lafer (2001):

O paradigma do processo de transformação do papel das fronteiras na América do Sul é o Mercosul, resultado de uma efetiva reestruturação, de natureza estratégica, do relacionamento Brasil-Argentina. Este relacionamento carregou na origem o peso da herança colonial, pois o que houve de rivalidade entre as Coroas de Portugal 
e Espanha teve no Prata seu foco principal. Na história, as relações dos dois países foram influenciadas por essa herança, tendo-se caracterizado por momentos de grandes convergências, entremeados por períodos de distanciamentos e desconfianças (LAFER, 2001, p. 58).

Calcada na ideia de que quem dominasse a bacia do Prata conquistaria o coração da América do Sul, a rivalidade entre o Brasil e a Argentina começou a ser forjada na primeira metade do século XIX, com disputas envolvendo fronteiras que se seguiram à conquista da independência dos dois vizinhos. Ganhou mais fôlego, em meados daquele século, com a briga pela influência sobre o Uruguai e cristalizou-se em episódios como a deposição do ditador argentino Juan Manuel Rosas, derrotado por uma revolução apoiada pelo Brasil e pelo Uruguai.

No início do século XX, ao longo dos dez anos em que José Maria da Silva Paranhos Júnior (1845-1912), o Barão do Rio Branco, esteve à frente do Ministério de Relações Exteriores brasileiro, houve momentos de tensão motivados pelo aumento do poderio bélico dos dois vizinhos e fomentou a concentração de quartéis e efetivos militares nos dois lados da fronteira. Os interesses argentinos sobre a Guerra do Chaco (1932-1935), uma disputa territorial entre a Bolívia e o Paraguai, serviriam de combustível para alimentar a desconfiança brasileira. Num passado mais recente, a construção da hidrelétrica de Itaipu na fronteira com o Brasil e o Paraguai acendeu o temor na Argentina de que, num eventual conflito entre os dois adversários históricos, o Brasil abrisse as comportas da usina, inundando Buenos Aires - isso, numa época em que as três nações eram governados por militares. O conflito de poder só seria encerrado em 1979, com o Tratado Multilateral Corpus-Itaipu. Miron (2002) relembra outra evidência da desconfiança mútua: as linhas férreas construídas pelo Brasil nas regiões fronteiriças têm bitola (distância entre os trilhos) incompatível com as da Argentina, com a finalidade de prevenir uma invasão do Brasil por meio das ferrovias — criando até hoje um problema para a circulação de mercadorias.

A rivalidade era tão duradoura que punha em dúvida a ideia de que os dois países pudessem usufruir de benefícios de uma integração econômica, como expôs Vargas (1997):

A análise dessa rivalidade e de seus contenciosos deu margem à convicção de que o ganho de um país correspondia necessariamente à percepção de perda por parte do outro, tanto em termos materiais, quanto de poder e prestígio. À sombra dessa percepção germinara a ideia de ameaça recíproca, que seria determinante no esforço para atingir a curto prazo o pleno desenvolvimento nuclear (VARGAS, 1997, p. 42$)$.

$\mathrm{Na}$ Argentina, o fiasco da invasão promovida pelo general-presidente Leopoldo Galtieri nas ilhas Falklands/Malvinas, em 1982, que resultou numa guerra perdida para a Inglaterra, colocou um dramático ponto final a oito anos de uma ditadura que deixou como legado um saldo de 30 mil mortos e desaparecidos políticos. Foram convocadas eleições no ano seguinte, vencidas pelo advogado Raúl Alfonsín (1927 — 2009). No Brasil, a transição foi mais lenta e suave. No período do último dos generais- 
-presidentes, João Figueiredo, foi aprovada uma lei de anistia que permitiu o retorno dos exilados políticos e os governadores voltaram a ser escolhidos por meio de eleições diretas em 1982. O primeiro presidente civil depois de 20 anos de ditadura veio em 1985, ainda assim graças a uma eleição indireta que culminou com a ascensão não do presidente eleito Tancredo Neves (1910-1985), que, doente, não conseguiu tomar posse, mas do vice José Sarney (1930), que até o penúltimo suspiro da ditadura perfilou-se ao lado dos militares. Entre 1983 e 1985, quando a Argentina já retomara a democracia mas o Brasil vivia o final do mandado do general-presidente João Batista Figueiredo, a diplo-macia dos dois países pouco conseguiu avançar em termos de relações cooperativas.

A redemocratização dos dois países, na década de 1980, foi decisiva para aparar as antigas desconfianças. Como ressaltam Freixo e Ristoff (2008):

o processo de integração regional se desenvolveu paralelamente ao processo de democratização de seus Estados-membros e o elemento “democracia”, ao menos no que se refere aos seus aspectos formais, passou a deter uma significativa importância nos discursos oficiais e foi considerado desde o início como um pressuposto para a integração (FREIXO \& RISTOFF, 2008, p. 42).

Esta posição é igualmente reforçada por Lafer (2001), que destaca:

Depois do equacionamento, em 1979, do problema da utilização das águas para fins energéticos que caracterizou o contencioso de Itaipu, a etapa mais significativa na preparação do Mercosul se situa após o término dos regimes militares, nos anos 80. Ela se deve às iniciativas dos Presidentes Sarney e Alfonsín que, lastreados nos precedentes de convergência, elevaram a um novo patamar o entendimento entre os dois países. O marco deste novo patamar foi o Tratado de Integração, Cooperação e Desenvolvimento de 1988. A sua moldura mais abrangente, de natureza política, compreendia a consolidação de valores democráticos e o respeito aos direitos humanos, passando por confidence building measures destinadas a reduzir tensões na área estratégico-militar, em especial no campo nuclear. Sobre esta base, o Tratado procurou estimular o desenvolvimento na difícil década econô-mica para a América Latina que foram os anos 80 (LAFER, 2001, p. 58-59).

No ano de 1985, os presidentes José Sarney e Raúl Alfonsín determinaram a criação de uma comissão mista para estudar as possibilidades de cooperação e integração econômica. Os estudos giraram em torno da possibilidade de pôr em ação um plano regional, uma vez que se acreditava que, apenas no âmbito de um bloco político e econômico, os países poderiam fazer valer os seus interesses no sistema internacional. Em 30 de novembro de 1985, Alfonsín e Sarney assinaram a Ata de Iguaçu, na qual expressaram suas vontades de acelerar o processo de integração bilateral. Criaram, para tal fim, uma comissão mista de alto nível, presidida por seus ministros de Relações Exteriores. $\mathrm{Na}$ mesma ocasião, assinaram a Declaração Conjunta sobre Política Nuclear, que proclamou os propósitos pacíficos da cooperação bilateral nessa área. $\mathrm{Na}$ esteira deste entendimento, colamos apontamento de Maria Cândida Galvão Flores, sobre a aproximação e o aprofundamento do diálogo entre Brasil e Argentina, nos governos Sarney e Alfonsín: 
O aprofundamento do diálogo entre Brasil e Argentina permitiu que, na década de 1980, tivesse início um processo real de integração econômica, impulsionado pela vontade política de ambos em fazer avançar, no terreno prático, a relativa complementaridade já existente entre as duas economias. No marco dessa inflexão na política exterior brasileira que privilegiava a cooperação no Cone Sul, os presidentes José Sarney e Raúl Alfonsín firmaram a Ata de Iguaçu, criando uma Comissão Mista de Alto Nível para a Cooperação e Integração Econômica Bilateral. Posteriormente, foi assinado o Tratado de Integração, Cooperação e Desenvolvimento, que previa a conformação de um espaço econômico comum em 10 anos, a crescente eliminação dos obstáculos alfandegários e não alfandegários, e a gradual liberalização do comércio bilateral. Esse tratado foi um marco no novo patamar de entendimento entre Brasil e Argentina por apresentar uma moldura mais abrangente de natureza política, que compreendia a consolidação dos valores democráticos e o respeito aos direitos humanos, além de medidas destinadas a reduzir tensões na área estratégico-militar, especialmente no campo nuclear (FLORES, 2005, p. 18).

A Ata de Iguaçu foi assinada numa solenidade no dia 29 de novembro de $1985 \mathrm{em}$ que os presidentes inauguraram uma ponte internacional que liga a cidade de Porto Meira, no Brasil, a Puerto Iguazú, na Argentina. No documento, os dois presidentes deixaram claro que um dos propósitos da integração era a necessidade de reforçar o poder de negociação dos dois países na comunidade internacional e de enfrentar os efeitos da crise, "evitando que os países da região continuem vulneráveis aos efeitos das políticas adotadas sem a sua participação”. No texto da declaração, os dois presidentes reiteraram a importância dos conceitos do Consenso de Cartagena, de junho de 1984, que estabelecia a necessidade de crescimento da economia dos países devedores, de aliviar o peso do serviço da dívida e a corresponsabilidade de devedores e credores. No último dos 32 tópicos da declaração, Sarney e Alfonsín reafirmaram enfaticamente que “o processo de democratização que vive o continente deverá conduzir a uma maior aproximação e integração entre os povos da região”.

A Declaração de Iguaçu criou um Grupo de Trabalho Conjunto de alto nível, presidido pelos Ministros de Relações Exteriores dos dois países, voltado também firmar os compromissos de cooperação nuclear pacífica. Tratou-se de um gesto simbólico, que ganharia contornos concretos sete meses mais tarde, com a assinatura da Ata para a Integração Argentino-Brasileira.

A importância desses acordos é ressaltada por Seitenfus (1989):

A assinatura destes acordos torna-se possível em razão da evolução política interna que conhecem os dois países nestes últimos quatro anos. Com efeito, e esta é uma de suas principais características, os acordos respondem a vontade política dos dois governos. O regime civil instalado em recente data nos dois países, após um longo período de militarismo, ressente-se da necessidade de fortalecer-se no âmbito internacional. Ao mesmo tempo, a tentativa de superação das rivalidades históricas entre os dois países faz com que a iniciativa tenha um significado especial, uma 
vez que se trata de uma ação do poder civil e democrático, contrariando a visão militarista predominante até então (SEITENFUS, 1989, p. 114).

A Ata diz que o Programa de Integração "será equilibrado no sentido de que não deve induzir uma especialização das economias em setores específicos; de que deve estimular a integração intrassetorial; de que deve buscar um equilíbrio progressivo, quantitativo e qualitativo, do intercâmbio por grandes setores e por segmentos através da expansão do comércio; propiciará a modernização tecnológica e maior eficiência na alocação de recursos nas duas economias”.

A Ata para a Integração Argentino-Brasileira foi assinada em Buenos Aires em julho de 1986, e instituiu o Programa de Integração e Cooperação Econômica (PICE), incumbido de propiciar a abertura seletiva dos respectivos mercados e o estímulo à complementação de setores específicos da economia dos dois países. Na primeira etapa do PICE, foram assinados 12 protocolos referentes a bens de capital, trigo, complementação de abastecimento alimentar, expansão do comércio bilateral, empresas binacionais, assuntos financeiros, fundo de investimentos, energia, biotecnologia, estudos econômicos, segurança nuclear e radiológica e cooperação aeronáutica. Tratava-se de um projeto orientado não somente para o desenvolvimento econômico como também para amplificar a força dos dois países no âmbito internacional.

Como observou Oliveira (1998):

O pioneiro Protocolo n. 1, Projeto Integrado de Bens de Capital, estabelecia medidas especiais, como "tarifa zero, exclusão de todo tipo de barreiras não tarifárias, mecanismos de expansão simétrica do comércio, incluindo cláusulas compensatórias de correção de assimetrias, nivelamento e uma margem comum de proteção face a terceiros países, outorgando a todos os bens, incluídos na lista comum, um tratamento igual ao outorgado a terceiros países, o que, na prática, indicava a intenção de se chegar, futuramente, a uma união aduaneira entre os dois países”. O Protocolo de Bens de Capital permaneceu prioritário entre as propostas do PICE, o qual englobava um contexto bilateral abrangente e diversificado: assuntos econômicos, financeiros, comerciais, políticos, militares, tecnológicos, nucleares, entre outros, contemplados a médio e longo prazo, condicionados às conjunturas macroeconômicas dos dois países, que marcam todo o processo. Do ponto de vista do intercâmbio econômico, os resultados internacionais foram satisfatórios. A Argentina duplicou suas vendas ao Brasil, que passou a ser seu primeiro mercado de exportação (OLIVEIRA, 1998, p. 15).

O PICE teve caráter gradual, flexível e equilibrado e previa tratamentos preferenciais frente a terceiros mercados. Essas medidas constituem o terceiro dos quatro eventos que Lafer (1997) considera fundamentais na história recente do relacionamento do Brasil com a Argentina, sendo que o primeiro foi o acordo trilateral:

O segundo foi a Guerra das Malvinas de 1982, que assumiu a proporção de uma crise internacional de grandes dimensões e levou o Brasil, num momento difícil, a 
afirmar publicamente, vis-à-vis a Grã-Bretanha e ao mundo, seu apoio à reivindicação argentina — ainda que não à sua efetivação pelo uso da força. $\mathrm{O}$ terceiro é mais difuso em termos cronológicos e talvez seja mais apropriadamente descrito como uma série de eventos derivados essencialmente da redemocratização de ambos os países em meados dos anos 80: a ênfase no desenvolvimento na democracia, no controle civil dos militares e na evolução de uma relação transparente e confiável na esfera nuclear. O quarto foi o estabelecimento do Mercado Comum do Sul (MERCOSUL) (LAFER, 1997, p. 249-265).

Um capítulo à parte envolveu a cooperação tecnológica, encarada não apenas como um instrumento de integração, mas de geração de economias de escala e de redução do fosso que separava os dois países das nações desenvolvidas.

Enquanto viviam sob ditaduras militares, os dois vizinhos encaravam o desenvolvimento da área nuclear como elemento essencial para alcançarem a autonomia tecnológica, embora, na Argentina, o interesse fosse claramente militar e, no Brasil, o discurso, calcado na doutrina de segurança nacional, enfatizasse mais a busca do desenvolvimento econômico (VARGAS, 1997, p. 45). Havia, é certo, algum tipo de intercâmbio, calcado em troca de documentos e visitas informais a instalações atômicas, que envolviam cientistas, não suas instituições. Nos anos de 1970, o general argentino Juan Guglialmelli chegou a propor a necessidade de integração nuclear entre Argentina e Brasil, por meio da unificação de seus programas atômicos, a fim de prevenir uma corrida armamentista, mas a tese foi rechaçada por militares de ambos os lados (OLIVEIRA, 1998).

Após a Segunda Guerra Mundial, Brasil e Argentina tornaram-se rivais regionais no desenvolvimento de tecnologia nuclear, ambos se negando a assinar compromissos de não proliferação de armas atômicas com o argumento de que privilegiariam os países já detentores de conhecimento nesse campo. A Argentina foi o primeiro país latino-americano a instalar uma usina nuclear de produção energética. A usina Atucha I, com componentes trazidos da Alemanha, começou a operar em 1974, ano em que teve início a construção da usina Embalse, com suporte canadense e componentes produzidos majoritariamente na Argentina. Conforme lembra Lazier (2006), a explosão de um artefato nuclear feita pela Índia em 1974 levaram tanto a Alemanha quanto o Canadá a colocarem obstáculos na cooperação atômica, o que levou a Argentina a buscar autonomia no enriquecimento de urânio.

No período do governo Médici, a diplomacia nuclear brasileira assumiu um tom especialmente crítico em relação ao Tratado de Não Proliferação de Armas Nucleares, que teve como pano de fundo a percepção de uma necessidade de amplificar a capacidade bélica do país com foco na rivalidade com a Argentina. De acordo com Cavagnari Filho (2000), havia dois cenários de guerra colocados para as Forças Armadas brasileiras, o combate a grupos opositores do regime, no campo interno, e a região do Prata, no front externo. A nuclearização das Forças Armadas era vista como essencial a fim de facilitar o incremento científico para o desenvolvimento de submarinos, mísseis balísticos e aviões subsônicos e garantir a supremacia regional. 
O Brasil optou por uma estratégia que, de um lado, propunha-se a importar tecnologia nuclear para alimentar a demanda crescente por energia e, de outro, desenvolver tecnologia autônoma. Isto se materializou na criação de dois programas: um oficial, para importar tecnologia, e outro, paralelo, que só seria reconhecido oficialmente em 1987 quando o país anunciou que conseguira enriquecer urânio e que segue até hoje, na tentativa de construir um submarino com propulsão nuclear.

Os debates pós-Guerra Fria sinalizam, não obstante outros quesitos, a vontade de países emergentes de participar de debates globais, dentre eles aqueles envolvendo aspectos econômicos, tecnológicos e inclusive de segurança internacional. Neste diapasão, surgem questões voltadas à redução de assimetrias econômicas e de fluxo de capitais e investimentos, alavancadas por negociações na esfera da ALADI, MERCOSUL, OMC E ALCA, dentre outros fóruns. E no plano de segurança internacional os debates seguem estes anseios. Segundo Lafer (2001):

O multifacetado entendimento argentino-brasileiro que está na base do Mercosul, assim como o entendimento entre a França e a Alemanha esteve na base da construção da Comunidade Europeia, tem também um alcance no plano da segurança internacional, no campo nuclear, que transcende a América do Sul. Com efeito, as confidence building measures dos anos 80 culminaram nos anos 90 na criação de um mecanismo formal de inspeções mútuas, abriram as instalações nucleares dos dois países à supervisão internacional, e permitiram a plena vigência do Tratado de Tlatelolco, de 1967, que proíbe as armas nucleares na América Latina. Com esses compromissos, o Brasil deu plena expressão internacional à norma estabelecida na Constituição de 1988 relativa ao uso exclusivamente pacífico da energia nuclear em território nacional (LAFER, 2001, p. 60-61).

Em novembro de 1983, poucos dias após a eleição de Raúl Alfonsín como presidente, o general-presidente Reynaldo Bignone enviou uma carta ao presidente brasileiro João Figueiredo anunciando que seu país conseguira enriquecer urânio pelo método de difusão gasosa. O projeto argentino de enriquecimento do urânio fora desenvolvido em segredo. Na carta ao colega brasileiro, Bignone ressaltava ainda que "o êxito alcançado tem importantes projeções de ordem regional pois constitui um significativo passo para a autossuficiência da América Latina numa área de tal transcendência no campo dos usos pacíficos da energia nuclear como a do enriquecimento do urânio, com a consequente implicação favorável no longo e difícil mas tão desejado processo de integração regional”. Temos, ainda, nas palavras de Vargas (1997):

Dois aspectos cabem ser observados na carta de Bignone: de um lado, a Argentina tinha uma política nuclear cujo objetivo último era afirmá-la como a grande potência latino-americana; e, de outro, o desenvolvimento nuclear era percebido pelas autoridades de Buenos Aires como alavanca para que a Argentina pudesse ter papel preponderante num projeto de integração regional na América Latina, o qual naquele momento era apenas incipiente e carecia de vontade política dos demais países da região (VARGAS, 1997, p. 47). 
A decisão de estabelecer colaboração no campo nuclear não se fez sem criar tensões. Alfonsín ofereceu compensações aos militares portenhos, ao sugerir que o desenvolvimento de estudos estratégicos conjuntos incorporasse as Forças Armadas de ambos os países. Sarney, por seu turno, evitou oficializar a promessa feita por Tancredo Neves a Raúl Alfonsín logo após a eleição indireta no sentido de promover inspeções conjuntas das instalações nucleares. Atribui-se o recuo ao receio de Sarney, alçado ao poder sem o respaldo popular de Tancredo, de melindrar os militares. Na prática, contudo, tais inspeções aconteceram - e ambos os presidentes, quando foram ao país vizinho, não se furtaram a fazer visitas a usinas e instalações nucleares, mostrando que o interesse de cooperar não era meramente retórico.

Conforme observou Miron (2002):

O militarismo foi, aos poucos, sendo considerado obsoleto e infundado também como consequência da mudança dos governantes. Os elevados dispêndios neste setor tornaram-se insustentáveis. Percebeu-se que segurança se obtém pela mútua dependência e o respeito recíproco, e não pela subjugação do outro. Dificilmente se ataca um aliado, no entanto, a mesma regra não vale para o opressor. $\mathrm{O}$ nacionalismo levado às últimas consequências também foi perdendo força. Percebeu-se que o amor à pátria é importante, mas não deve ser usado como fundamento para o desprezo dos ímpares (MIRON, 2002).

Vargas (1997) complementa:

Sendo Brasil e Argentina os dois países mais avançados no campo nuclear na América Latina, as visitas recíprocas às respectivas instalações determinaram uma alteração no conhecimento de cada país sobre a capacitação do outro. A consequência prática foi uma progressiva transformação dos interesses brasileiros e argentinos em matéria nuclear, contribuindo para uma cooperação que seria plasmada em tratados internacionais e abrangeria instâncias multilaterais de participação universal, como a AIEA (VARGAS, 1997, p. 53).

A questão nuclear, que teve um lugar discreto nos primórdios da integração, acabaria tendo o dom de bilateral: de início, figurou discretamente no processo, passando depois a ocupar posição de destaque e constituir um dos principais triunfos políticos da integração, além de fornecer um novo perfil aos dois Estados junto às articulações dinâmicas das relações internacionais.

A consolidação institucional desse processo deu-se em novembro de 1988, com a assinatura pelos presidentes Sarney e Alfonsín do Tratado de Integração, Cooperação e Desenvolvimento, que propunha no prazo de dez anos a harmonização de políticas nos campos aduaneiro, comercial, agrícola, industrial, e transporte e comunicação.

Cumpre lembrar, ainda, que a criação do Mercosul deve-se ao permissivo constante no art. 24 do GATT, que por meio da ALADI, permitiu ao Brasil, Argentina, Paraguai e Uruguai formarem o bloco. Segundo Araújo (2008), o Mercosul: 
foi negociado no âmbito da ALADI por meio do Acordo de Complementação Econômica n. 18 (ACE-18). Atualmente, a ALADI é foro para a negociação de inúmeros acordos de integração de seus Estados-membros, tendo também a tarefa de elaborar uma base de informações e dados comerciais e econômicos (ARAÚJO 2008, p. 114).

\section{O CONTEXTO INTERNACIONAL}

As modificações no parâmetro brasileiro de políticas externas, em especial no que toca às relações praticadas com a Argentina, estiveram estreitamente vinculadas às mudanças conjunturais da década de 1980, que, por sua vez, decorreram de um processo já em curso desde a década de 1970. Porém, a distensão da Guerra Fria no cenário externo e a redemocratização no âmbito interno brasileiro, aprofundaram as alterações que moldaram a base de uma nova feição no relacionamento entre Brasil e Argentina, representada pelo investimento mútuo na construção de sólidos pilares de confiança.

No Brasil e na Argentina, a explosão da dívida externa e a consequente crise econômica contribuíram para o desentendimento entre os dirigentes responsáveis pela manutenção do regime ditatorial, fato que facilitou, no âmbito brasileiro, a consolidação do processo de abertura política lenta e gradual. A despeito da grande mobilização pública organizada na época pela reivindicação de eleições diretas para o cargo presidencial, Tancredo Neves foi eleito por meio de eleição indireta, pelo Colégio Eleitoral, mantendo-se a preponderância da elite tradicional nas decisões políticas do país. O governo Sarney (1985-1989) reuniu tanto elementos de continuidade quanto de ruptura em relação aos seus antecessores militares. Em termos de continuidade, pôde ser observado nos primeiros anos um elevado grau de adesão aos princípios de política externa da era Figueiredo. Para Sennes (2003, p. 35-36), embora ainda seja recorrente a associação de paradigmas específicos de política externa a determinados governos, buscando-se assim diferenciar as linhas de relações exteriores adotadas em diferentes mandatos presidenciais, deve-se relevar que o conjunto de "percepções, perspectivas, estratégias e valores costumam variar em menor grau e se modificam mais lentamente do que mandatos presidenciais poderiam supor". Ao longo do governo, porém, os referidos traços de continuidade forma descartados, em grande medida por influência das drásticas alterações ocorridas no cenário internacional.

As principais mudanças promovidas na política externa foram relacionadas às transformações nas relações entre os países desenvolvidos e os em desenvolvimento ocorridas, principalmente, em razão da política exterior adotada na presidência de Ronald Reagan (1981-1989) nos Estados Unidos, que contribuiu para o enfraquecimento do multilateralismo e instituiu como meta a liberalização da economia mundial, o que redundou em aumento da fragilidade econômica dos países subdesenvolvidos (SENNES, 2003, p. 66). Em resposta, a política externa do governo Sarney recorreu à diversificação de parcerias multilaterais e bilaterais para contrabalançar a supremacia norte-americana e das grandes potências europeias, buscando arranjos que estivessem mais ligados às necessidades de recuperação e crescimento da economia brasileira (PEREIRA, 2003, p. 10). 
O governo Sarney partia do pressuposto de que o país deveria limitar suas críticas ao sistema internacional e explorar suas oportunidades individuais. Entendia-se que a política externa deveria ser utilizada como instrumento do projeto nacional planejado pelo governo. Alguns obstáculos foram encontrados em virtude das fragilidades econômicas que distanciavam o país dos centros desenvolvidos e por atritos com o governo norte-americano, que acabaram desgastando a imagem brasileira e diminuindo a sua credibilidade junto a parceiros internacionais. Além disso, o nível elevado de endividamento externo e o insucesso do plano de reajuste econômico foram vistos como consequências do nacionalismo econômico, fato que deixou os investidores apreensivos (PEREIRA, 2003, p. 93).

Com isso, na estratégia de desenvolvimento brasileira da década de 1980 havia a ideia de que a abertura de novas frentes de cooperação internacional ajudaria a atenuar as pressões de países desenvolvidos e ampliaria as opções de crescimento econômico sustentável. Nas relações bilaterais, havia dois objetivos principais:

1) diversificar as relações com as Grandes Potências e países desenvolvidos, reduzindo a intensidade de suas relações com os Estados Unidos e incrementando contatos políticos e econômicos com a Europa e Japão;

2) ampliar e aprofundar suas relações econômicas e políticas com as pequenas potências, aproveitando as vantagens comparativas que possuía em relação a esses países (SENNES, 2003, p. 45).

A tentativa de articular canais autônomos de relacionamento diplomático por meio de parcerias bilaterais e da aproximação com a América Latina, assim como a manutenção de uma postura autônoma em relação a questões de competição econômica levaram a recorrentes atritos entre Brasil e Estados Unidos. Contudo, tais enfrentamentos não estiveram ligados a propostas de reforma do sistema internacional, mas sim ao fortalecimento do Brasil dentro do mesmo.

Para Sennes (2003), a política externa brasileira orientou-se pela moderação, o que muitas vezes pareceu contraditória.

O movimento por maior autonomia e espaço de manobra internacional (...) não incluiu propostas de rompimento com a ordem pública vigente. Buscava-se tão somente obter em todos os âmbitos os espaços político e econômico necessários para assegurar o prosseguimento do processo de desenvolvimento do país. Esta ponderação é necessária na medida em que a retórica política e diplomática que acompanhou tal processo, tomada em si mesma, pode induzir ao erro de se superdimensionar o grau de enfrentamento político real operado ao longo desse período (SENNES, 2003, p. 58).

Diante desse cenário internacional, a política externa brasileira orientou-se pela intenção de diminuir a presença norte-americana na região mediante a intensificação das relações interestatais regionais. A expectativa brasileira com essa estratégia era de que a integração regional cumprisse a função de minimizar a influência dos Estados 
Unidos na América Latina e, dessa, maneira, permitisse que os países da região tivessem maior autonomia nos seus planos políticos e econômicos.

Seguindo essa lógica, o Brasil dispôs-se a harmonizar e a promover a cooperação com os seus vizinhos. Contudo, a integração não seria de forma alguma viável se persistissem as suspeitas de que os países mantinham projetos militares, havendo, portanto, a necessidade de criação de um ambiente confiável por meio de medidas de transparência e confiança mútua.

No campo econômico, o governo de Raul Alfonsín criou o Plano Austral para combater a inflação e promover o desenvolvimento econômico do país. Tal plano econômico logrou êxito inicialmente, mas, após alguns meses, a inflação foi retomada e o panorama econômico foi se deteriorando.

O governo de Raul Alfonsín deu uma guinada no seu plano de inserção internacional, procurando um alinhamento com os Estados Unidos, após o distanciamento dos países desenvolvidos decorrente da Guerra das Malvinas. Claros exemplos dessa aproximação foram o apoio dado aos norte-americanos nas crises da América Central e na oposição ao regime cubano manifestada pelo governo da Argentina (SEITENFUS, 2002, p. 4).

Nesse cenário, o Brasil também apresentava-se como um parceiro viável e acessível também interessado em fortalecer os seus laços regionais.

Lafer (1997) introduziu um elemento interno relevante para o apaziguamento das relações entre Brasil e Argentina: a redemocratização, que remeteu à posse de Alfonsín na Argentina em 1983 e de Sarney no Brasil em 1985. Todavia, ele contestou o protagonismo dos governos civis nesse processo, uma vez que os primeiros passos para a distensão foram dados ainda sob os regimes militares. Segundo o autor, o que de fato modificou a situação foi a "chegada da democracia e a preocupação com os direitos humanos”. Nas palavras de Lafer (1997):

Se a coincidência de regimes autoritários favorecia uma percepção algo semelhante na ordem internacional e da ordem interna, alimentava também a suspeita mútua no plano bilateral e sub-regional. A simultaneidade agora de regimes democráticos desarmava a tensão, e agregava um elemento de parceria na necessidade que sentiam os dois governos de afirmar e consolidar o controle civil e democrático sobre os militares (LAFER, 1997, p. 254).

Seguindo outra vertente, para Miyamoto (2000), a instauração dos regimes democráticos impulsionou a construção da confiança mútua na medida em que, sob esta nova configuração da política interna, as políticas externa e militar deixaram, aos poucos, de ser pautadas no binômio segurança e desenvolvimento, já que sob os governos militares "tudo era pensado sob o prisma da segurança nacional". O autor agrega que:

(...) em termos de atuação do país nos cenários regional e internacional, pelo menos dois locais de decisão eram significativos: o Ministério das Relações Exteriores e as 
Forças Armadas, estas últimas representadas, principalmente, pelo Conselho de Segurança Nacional através da Secretaria-Geral. Em tópicos que diziam respeito às negociações políticas com outros países, nos planos bilateral e multilateral, o Itamaraty detinha maior capacidade de decisão. $\mathrm{O}$ mesmo, todavia, não se pode afirmar quando algum item relativo à sobrevivência das instituições e da defesa das fronteiras estava de alguma forma em jogo.

Assim quando duas instâncias tinham perspectivas diferentes, prevalecia rotineiramente a visão militar, arbitrada pelo Conselho de Segurança Nacional, considerando que o regime era de natureza castrense. Destarte, o problema das fronteiras era visto e pensado sob o prisma da segurança nacional, sob a ótica do binômio segurança e desenvolvimento (MIYAMOTO, 2000, p. 443).

Para Carasales (1997, p. 73), a mudança de regime no Brasil propiciou melhor correspondência de objetivos com a Argentina, entre os quais destacava-se a cristalização da democracia. De acordo com o autor, os acordos bilaterais estabelecidos antes da reinauguração da democracia no Brasil tiveram sua importância mais centrada na mudança de mentalidade política do que nos resultados práticos. Isto porque o fato da Argentina ter retornado ao regime democrático em 1983, dois anos antes do Brasil, antecipou sua proclamação da democracia como valor supremo, o que dificultava o entendimento com um país que ainda era governado por militares. A partir de 1985, a interlocução realizar-se-ia entre governantes civis, permitindo o estabelecimento de identidades.

\section{O CONTEXTO ECONÔMICO}

Enquanto o Brasil dos anos 1970 ainda era fortemente dirigista, na Argentina já se experimentavam alguns instrumentos de caráter neoliberal na condução da política econômica, que levaram a um processo de desindustrialização, conforme Vieira Santana (2006):

A trajetória da Argentina, por exemplo, veio de um processo de desindustrialização desde a ditadura, cujo governo militar via na desestruturação de setores produtivos um meio de luta política interna contra o peronismo, e que se acentuou nos anos 1990 com a abertura comercial, privatizações e o desmonte dos instrumentos de coordenação do Estado portenho. No Brasil, por outro lado, a ditadura procurou articular autoritariamente seu modelo de desenvolvimento, estruturando as cadeias produtivas nacionais e ampliando o processo de substituição de importações, com ênfase na coordenação e incentivo promovido por esferas burocráticas associadas a empresas estatais e bancos públicos (VIEIRA SANTANA, 2006, p. 1810).

Nas décadas de 60, 70 e 80, a ausência de democracia aprofundou o distanciamento dos países, agravando-se tal fato pela ausência de democracia pela imposição de governos e regimes militares autoritários, com seus modelos estatais fundados em questões de 
soberania e de territorialidade, elementos contrários a processos de integração. Já na década de 80, quando sinais de redemocratização surgiam no horizonte da América Latina, a globalização trazia consigo novas necessidades e novas roupagens para os antigos discursos de desenvolvimento e integração, especialmente aqueles oriundos da década de 1960 da CEPAL.

A saída integracionista dos anos de 1980 pode ser entendida como possibilidade de recuperação de seu parque industrial e melhoria de seus níveis de exportações. De acordo com Onuki (2004): “na época a maior parte dos empresários argentinos nutria a percepção de que o Mercosul seria uma oportunidade para que o seu parque industrial pudesse ser modernizado e tornar-se competitivo no mercado mundial”.

Verificamos no período pós-Guerra Fria a acentuação do processo de globalização, encerrando o marco bipolar que dividia as relações internacionais. Neste contexto, a América Latina abarcava duas questões fundamentais, sendo uma a superação de sua posição marginalizada durante o período da Guerra Fria, e outra a de buscar seu lugar ao sol de forma estratégica frente ao mercado globalizado. Karina Mariano (2007) sintetiza:

De modo geral, pode-se dizer que a estratégia dos países latino-americanos com esse propósito seguiu um plano comum, embora, aplicado de forma diferenciada: na esfera política optaram pela democratização dos regimes; na econômica, adotaram um receituário neoliberal, marcado por um novo papel para o Estado e pela liberalização econômica (para nações como o Brasil, isso representou abandonar sua política econômica baseada no protecionismo e substituição de importações); e no âmbito internacional, impulsionar os projetos de integração regional. Esta não é apenas um processo de redução tarifária entre nações ou um mecanismo de inserção comercial num mundo globalizado, mas sim um aspecto dessa nova configuração do Estado. Isto é, o processo de integração regional passa a fazer parte da nova forma de funcionamento dos governos (MARIANO, 2007, p. 125).

Nos termos apresentados por Mariano, verificamos não somente o pensamento, mas também a ação dos países da América Latina no sentido de conjugar o processo de redemocraticação com o desenvolvimento, mediante processos de integração regional. Assim, o processo de integração não é visto pelos países da América Latina como um processo apenas de abertura comercial, e sim, como uma estratégia firme dos governos voltada para a inserção internacional, tanto política quanto econômica.

A retomada da ideia da integração tornava-se óbvia num momento em que as economias mais ricas expandiam-se e buscavam formar grandes espaços econômicos, a exemplo do Acordo de Livre Comércio entre os Estados Unidos e o Canadá, de 1987, que sete anos mais tarde incorporaria o México no Acordo de Livre Comércio da América do Norte (NAFTA).

Conforme escreveu Rafael Villa (2006):

O exemplo do sucesso de países da Europa Ocidental, enfatizando a interdependência entre democracia e bem-estar social, a regulação dos nacionalismos e os problemas 
de segurança regional, talvez tenha animado as elites brasileiras e argentinas, desde os governos Sarney e Alfonsín, respectivamente, com o objetivo de que, dada a condição de país em desenvolvimento, a eficácia de ações individuais com tendência a procurar soluções para o problema da segurança dependa de uma assunção do núcleo do discurso democrático global na forma de "liberalismo qualificado". Está claro para as elites brasileiras que formulam a política externa para a América do Sul que a identidade negativa do "subimperialismo brasileiro", construída de longa data, mas acentuada nos anos do regime autoritário pós-64, só pode ser desconstruída seguindo-se um curso de ação que privilegie a atenuação dos acervos imagéticos do poder, substituindo-os por um nacionalismo cívico no sentido mencionado por Ikenberry (2002). Isto é, o enraizamento em ideais democráticos e em regras de direito compartilhadas fornece uma via potencial para a liderança branda em âmbitos regionais por ser menos propenso às políticas de poder (VILLA, 2006, p. 79).

Freixo e Ristoff (2008) chamam atenção para a vulnerabilidade crescente da América Latina naquela época:

Ao retornar ao regime democrático, os países latino-americanos, recém-saídos de governos ditatoriais, eram elogiados e aplaudidos pelos Estados desenvolvidos. No entanto, esses Estados praticamente nada fizeram para ajudar no aprofundamento dos processos de democratização na região, mantendo-se estes limitados aos seus aspectos políticos formais; pelo contrário, o diálogo norte-sul continuou sem render frutos e os países centrais fizeram muito poucas cessões nos organismos internacionais. Os protecionismos das nações industrializadas se mantiveram e apesar dos discursos favoráveis à liberalização dos fluxos de comércio internacional - principalmente após a criação da Organização Mundial do Comércio (OMC), em 1995 - elas continuaram a manter amplos setores de suas economias protegidos, notadamente o agropecuário, muitas vezes apelando para barreiras comerciais não tarifárias. Desta forma, havia uma tentativa de se impor uma "liberalização de mão única”, claramente prejudicial aos interesses dos países periféricos. Por outro lado, continuavam difíceis, praticamente sem nenhum avanço, as (re)negociações das dívidas externas das nações latino-americanas (FREIXO; RISTOFF, 2008, p. 41).

Para o Brasil e a Argentina, o incremento do intercâmbio comercial casava-se com a necessidade de promover reformas que estabilizassem suas economias. Ambos os países estavam submetidos a crises fiscais agudas e estavam sofrendo com taxas de inflação elevadas. Essa situação levou os governos da Argentina e do Brasil a solicitarem apoio do Fundo Monetário Internacional (FMI), que impôs ajustes estruturais de alto custo social. Aumentavam as pressões pela abertura da economia, justificadas pelo avanço da globalização e também pela necessidade de reencontrar o caminho do desenvolvimento. Reforçamos esta afirmação segundo lição de Furtado:

A pressão conjugada da oferta de mão de obra gerada pelo crescimento demográfico e da rigidez da procura de produtos primários nos mercados internacionais levou, 
no passado, os países periféricos a buscar o caminho da industrialização. Contudo, poucos dentre esses países reuniam as condições de dimensão demográfica, potencial de recursos naturais e liderança empresarial para fundar a industrialização no desenvolvimento do mercado interno. A grande maioria dos países pobres que buscam industrializar-se ficam na dependência de acesso marginal ao mercado internacional como subcontratistas de empresas transnacionais. Foram poucos os que avançaram na construção de um sistema econômico com certo grau de autonomia na geração da demanda efetiva e no financiamento dos investimentos reprodutivos (FURTADO, 2007, p. 42).

Nesse contexto econômico, o modelo de desenvolvimento de ambos os países requereria a consideração de um modelo de integração regional, uma vez que a ajuda fornecida pelo FMI era condicionada à abertura da economia. Segundo Camargo (1989), o novo modelo de integração incorporaria a ideia de cooperação em várias dimensões além da comercial, como a produtiva e tecnológica e a cultural, e traria uma visão clara da importância da política em qualquer estratégia de desenvolvimento. A redemocratização do Brasil e da Argentina, ressalta a autora, estão longe de ser dados acidentais neste processo:

Quando digo que a mudança de regime foi uma condição necessária, quero referir-me ao fato de que, num contexto político autoritário em que o arbítrio, o segredo e a discriminação fazem parte do próprio exercício do poder, dificilmente propostas de cooperação e de desenvolvimento regional poderiam encontrar campo de atuação. (CAMARGO, 1989, p. 52).

Os dois governos democráticos enfrentavam o desafio de reorientar suas economia abaladas pelo peso da dívida contraída pelos militares e pela escassez de novos créditos, além de enfrentar o desafio de se modernizar e competir internacionalmente - e amadureceram juntos a ideia de que este processo de reconversão e expansão teria mais vantagens se fosse encarado em conjunto.

\section{Conclusões}

A redemocratização, em meados dos anos de 1980, teve papel de protagonista na integração entre Brasil e Argentina e na criação do Mercado Comum do Sul, na década seguinte. A rivalidade histórica entre os dois países e as disputas geopolíticas fomentadas sobretudo por governantes militares neutralizaram esforços diplomáticos, iniciativas empresariais e propostas de economistas que, desde o século XIX, sugeriam a necessidade de aproximar os dois vizinhos para que juntos tivessem mais chance de superar a dependência externa e os dilemas do desenvolvimento. Esse quadro sofreu uma transformação profunda com o encerramento dos ciclos autoritários na Argentina, em 1983, e no Brasil, dois anos mais tarde.

Segundo Fernando Henrique Cardoso, “com o retorno à democracia, ocorrido em meados dos anos 80, abrimos o caminho para um melhor relacionamento com a 
comunidade internacional em todos os temas que, no passado, haviam sido sensíveis, como os direitos humanos, o desenvolvimento social, o meio ambiente ou a não proliferação nuclear" (CARDOSO, 2001, p. 6).

Neste sentido, o amplo reconhecimento do processo de redemocratização na América do Sul e suas contribuições até hoje encontram eco, tanto na doutrina quanto na mídia e por parte da comunidade jornalística, nacional e internacional. Nesta direção, verificamos, por exemplo, recente reforço deste reconhecimento, apontando a importância deste processo e das medidas regionais para sua consolidação, destacando Larry Rohter que "quando essas ditaduras caíram, no entanto, os novos líderes civis tomaram medidas para construir a confiança mútua e negociaram os tratados que levaram à formação do Mercosul e ao abandono da corrida de armas nucleares regional. Esse é um dos grandes feitos da diplomacia moderna, não apenas da América Latina, mas do mundo, e José Sarney e Raúl Alfonsín merecem um enorme crédito por controlarem as Forcas Armadas, revertendo 150 anos de suspeita mútua e começando a construir uma parceria econômica e política. O mundo conhece e admira isso, como ficou claro quando o presidente Bill Clinton foi à Índia e ao Paquistão em 2000 e instou aqueles dois países a abandonarem sua corrida de armas nucleares, citando o Brasil e Argentina como exemplos de como a cooperação pode beneficiar países e povos” (ROHTER, 2007, p. 266).

$\mathrm{O}$ advento de grandes blocos comerciais, a exemplo do Nafta e da Comunidade Econômica Europeia, também ajudaram a reabilitar a ideia da integração dos dois países, adormecida desde o fracasso da ALALC (Associação Latino-Americana de Livre Comércio), nos anos de 1960. O retorno à democracia coincidiu com um notável crescimento da vulnerabilidade externa dos dois países, num período marcado pela crise da dívida, pela estagnação e pela escalada da inflação. A integração despontou como uma estratégia possível para amplificar o poder de barganha em negociações multilaterais, num momento em que os dois países perderam o controle e a influência sobre o destino das crises que os assolavam, além de atrair a atenção da comunidade internacional para os esforços de estabilização num novo cenário político.

O estreitamento do comércio bilateral mostra que a estratégia produziu efeitos duradouros. De acordo com Plá (1992), a crise financeira do início dos anos de 1980 levou os dois países a seguirem estratégias de contenção de importações que reduziram o comércio bilateral, limitado, entre os anos de 1982 e 1985, a apenas $55 \%$ do volume global comercializado em 1980. Os acordos de 1986, favorecidos por uma conjuntura mundial expansiva, fortaleceram o comércio bilateral, que, em 1989, chegou a recuperar o nível de 1980.

$\mathrm{Na}$ década de 1990, os efeitos foram eloquentes. Dados da Camex mostram que, em 1990, o Brasil exportou US $\$ 645$ milhões e importou US $\$ 1,399$ bilhão em produtos argentinos. Seis anos depois, o volume de exportações saltou para US $\$ 5,1$ bilhões e o de importações, para US\$ 6,8 bilhões. Depois de alcançar o melhor resultado em 1997, com US $\$$ 6,7 bilhões de exportações e US $\$$ 8,032 bilhões de importações, o comércio entre os dois países viveu um período de declínio. Em 1999, as exportações caíram 20,5\% em razão da desvalorização cambial no Brasil e a problemas internos na Argentina. As 
importações de produtos argentinos caíram 27,65\%. De janeiro a novembro de 2001, o comércio entre os dois países enfrentou nova queda em virtude do agravamento da crise argentina. As exportações (de US\$ 4,747 bilhões) foram 16,31\% menores do que as do mesmo período do ano anterior e as importações (de US $\$$ 5,836 bilhões) caíram 6,86\%.

Nos últimos anos, contudo, o comércio voltou a crescer, ainda que tenha avançado a importância da China como parceira de ambos os países. A Argentina, atualmente, é o terceiro principal destino das exportações brasileiras, superada apenas por China e Estados Unidos. Segundo dados fornecidos pelo Ministério do Desenvolvimento, nos primeiros sete meses de 2010, as vendas brasileiras à Argentina somaram US\$ 9,4 bilhões, 57,3\% mais do que no mesmo período no ano anterior, de US\$ 6 bilhões. Com esse desempenho, a participação argentina no total das exportações brasileiras avançou de $8,6 \%$ para $10,6 \%$. Os principais produtos brasileiros exportados à Argentina nesse período foram: automóveis de passageiros (15,7\%); autopeças (10,1\%); aparelhos transmissores e receptores (4,6\%); veículos de carga (4,6\%); e minérios de ferro e seus concentrados $(4,3 \%)$.

Nas importações, o país também ocupa a terceira colocação dentre os que mais vendem para o Brasil, atrás dos Estados Unidos e da China. As compras brasileiras provenientes da Argentina atingiram US $\$ 8$ bilhões no acumulado dos sete meses de 2010, contra US $\$ 6$ bilhões em igual período de 2009, o que representa um acréscimo de $33,7 \%$. Os principais produtos argentinos importados pelo Brasil no período foram: automóveis de passageiros (22,5\%); veículos de carga (10,2\%); trigo em grãos (8,2\%); naftas $(7,4 \%)$ e autopeças (5,6\%) (Brasil, 2010).

\section{REFERÊNCIAS BibLIOGRÁfiCAS}

ARAÚJO, Leandro R. Associação Latino-Americana de Integração (ALADI). In: MERCADANTE, Araminta de Azevedo; CELI JUNIOR, Umberto; ARAÚJO, Leandro Rocha de (coords.). Blocos econômicos e integração da América Latina, África e Ásia. Curitiba: Juruá, 2008.

BRAGA, Márcio B. Integração econômica regional na América Latina: uma interpretação das contribuições da CEPAL. Cadernos Prolam/USP-Brazilian Journal of Latin American Studies, Programa de Pós-Graduação em Integração da América Latina da Universidade de São Paulo, São Paulo, v. 1, jan./dez. 2002.

BRASIL e Argentina discutem relações comerciais em reunião bilateral. MDIC, Notícias, Brasília, 18 ago. 2010. Disponível em: <http://www.desenvolvimento.gov.br/sitio/interna/noticia.php? area $=1 \&$ noticia $=10024>$.

BUENO, Clodoaldo. Pan-Americanismo e projetos de integração: temas recorrentes na história das relações hemisféricas (1826-2003). Política Externa, v. 13, jun./jul./ago. 2004.

CAMARGO, Sonia. Brasil-Argentina: a integração em questão. Contexto Internacional, Rio de Janeiro, v. 4, n. 9, 1989.

CARASALES, Julio César. De rivales a sócios: el proceso de cooperación nuclear entre Argentina y Brasil. Buenos Aires: Grupo Latinoamericano, 1997. 
CARDOSO, Fernando Henrique. A política externa do brasil no início de um novo século: uma mensagem do Presidente da República. Revista Brasileira de Política Internacional, ano 44, n. 1, 2001.

CAVAGNARI FILHO, Geraldo L. Estratégia e defesa (1960-1990). In: ALBUQUERQUE, José Augusto Guilhon. Sessenta anos de política externa brasileira (1930-1990): prioridades, atores e políticas. São Paulo: Annablume/NUPRI/USP, v. IV, p.119-148, 2000.

CHIARELLI, Carlos Alberto Gomes. Temas de integração com enfoques no Mercosul. São Paulo: LTr, v. 1, 1997. p. 20-21.

FERNÁNDEZ, Raquel. Returns to regionalism: an evaluation of non-traditional gains from RTAs. NBER Working Paper, n. 5970, p. 14, 1997.

FLORES, Maria Cândida Galvão. O Mercosul nos discursos do governo brasileiro. Rio de Janeiro: FGV Editora, 2005.

FREIXO, Adriano; RISTOFF, Taís. Democracia e integração regional: a experiência do Mercosul. Agenda Social, Universidade Estadual do Norte Fluminense (UENF), v. 1, p. 32-47, 2008.

FURTADO, Celso. O capitalismo global. 7. ed. São Paulo: Paz e Terra, 2007.

GUIMARÃES, Samuel Pinheiro. O mundo multipolar e a integração sul-americana. Rio de Janeiro: Centro Brasileiro de Estudos Latino-Americanos (Cebela), dez. 2007. Disponível em: <http:// www.cep.cl/Cenda/Cen_Documentos/Integracion/Pinheiro.doc $>$.

HERNANDES, Alessandra C. O contexto jurídico da integração regional. Artigo apresentado no Primer Congreso Internacional del Mercosul, Ciudad de La Plata, 2004. Disponível em: <http:// www.colproba.org.ar/mercosur/73.asp>.

LAFER, Celso. A identidade internacional do Brasil e a politica externa brasileira: passado, presente e futuro. São Paulo: Perspectiva, 2001.

Relações Brasil-Argentina: alcance e significado de uma parceria estratégica. Contexto Internacional, v. 19, n. 2, 1997.

LAZIER, Tiago C. Política externa estadunidense: os programas nucleares de Argentina, Brasil e Irã. Conjuntura Internacional, Belo Horizonte, n. 28, p. 1-11, out. 2006. Disponível em: <http:// www.pucminas.br/conjuntura/index 1.php?tipo_form=equipe\&pagina=1 $199 \& \mathrm{menu}=$ $\&$ cabecalho=29\&lateral $=6>$.

LERDA, Juan Carlos; MUSSI, Carlos. Coordenação de políticas macroeconômicas no contexto da integração argentino-brasileira: uma avaliação crítica. In: BAUMANN, Renato; LERDA, Juan Carlos (orgs.). Brasil, Argentina e Uruguai: a integração em debate. Brasília: Editora Marco Zero, 1987.

MAGARIÑOS, Gustavo. Integración económica latinoamericana: proceso Alalc/Aladi 1950/2000. Integração Econômica Latino-Americana: processo ALALC-ALADI, 1950-2000. Montevidéu: BID. INTAL, ALADI, 2005.

MARIANO, Karina Pasquariello. Globalização, integração e o Estado. Lua Nova - Revista de Cultura e Política, n. 71, São Paulo, CEDEC, 2007.

MIRON, Rafael B. A democracia como pressuposto à integração. Jus Navegandi, Teresina, ano 6, n. 56, abr. 2002. Disponível em: <http://jus2.uol.com.br/doutrina/texto.asp?id=2864>.

MIYAMOTO, Shiguenoli. A política de defesa brasileira e a segurança regional. Contexto Internacional, Rio de Janeiro, v. 22, n. 2, jul./dez. 2000. 
OLIVEIRA, Odete M. A integração bilateral Brasil-Argentina: tecnologia nuclear e Mercosul. RBPI: Revista Brasileira de Política Internacional, Brasília, Instituto Brasileiro de Relações Internacionais, v. 51, n. 1, p. 5-23, 1998.

ONUKI, Janina. O Mercosul na geladeira. Relnet. Site de referência de Relações Internacionais, 19 jul. 2004. Disponível em: <http://www.caeni.com.br/index.php?option=com_content\&task=view\&id= 33\&Itemid>.

PEREIRA. A política externa do governo Sarney. Porto Alegre: UFRGS, 2003.

PINTO, Hugo Eduardo Meza; BRAGA, Marcio Bobik. A lógica do regionalismo na América Latina e a comunidade Andina das nações. Texto apresentado em seminário do Programa de Integração da América Latina/UPS em 22.5.2006. Disponível em: <http://www.usp.br/prolam/downloads/ versao3.doc $>$.

PLA, Juan A. O comércio Brasil-Argentina: tendências observadas nos últimos 20 anos. Indicadores Econômicos - FEE, Porto Alegre, v. 20, n. 1, p. 158-174, 1992.

ROHTER, Larry. Deu no New York Times. O Brasil segundo a ótica de um repórtes do jornal mais influente do mundo. Rio de Janeiro: Objetiva, 2007.

SANTANA, Carlos H. Vieira. Política industrial do governo Lula. Possibilidades de trajetória. Cadernos de Sociologia e Política, IUPERJ, Instituto Universitário de Pesquisas do Rio de Janeiro, n. 9, p. 1809-1814, dez. 2006.

SANTORO, Mauricio. O modelo chileno e os dilemas da América do Sul. Observatório Político Sul-Americano: IUPERJ, 2005, p. 5. Disponível em: <http://observatorio.iuperj.br/pdfs/12_artigos_ Texto_do_Mauricio_Santoro2.pdf>.

SARNEY, José. Direção correta. Folha de S. Paulo em 11 de junho de 1999. Site da embaixada argentina no Brasil. Disponível em: <http://www.embarg.org.br>.

SEITENFUS, Ricardo. A cooperação argentino-brasileira: significado e perspectivas. Lua NovaRevista de Cultura e Política. São Paulo: Centro de Estudos da Cultura Contemporânea, n. 18. p. 107-126, p. 114, ago. 1989.

. Metamorfoses argentinas: da prata ao caos. Estudos avançados, São Paulo, v. 16, n. 44, apr. 2002. Disponível em: <http://www.scielo.br/scielo.php? script=sci_arttext\&pid=S0103-40 142 002000100004\&lng=en\&nrm=iso > Acesso em: 10.12.2010. doi: 10.1590/S0103-40142002000100004.

SENNES, Ricardo. As mudanças da política externa brasileira nos anos 80. Porto Alegre: UFRGS, 2003.

VALENTINI, Rafael Escobar Tobias. Democracia e integração na América Latina: frustrações e perspectivas. Cenário Internacional, São Paulo, 10 de maio de 2007. Disponível em: <http:// www.cenariointernacional.com.br/default3.asp?s=artigos2.asp\&id $=27>$.

VARGAS, Everton Vieira. Átomos na integração: a aproximação Brasil-Argentina no campo nuclear e a construção do Mercosul. RBPI: Revista Brasileira de Política Internacional, Brasília: Instituto Brasileiro de Relações Internacionais, v. 40, n. 1, p. 41-74, 1997.

VERSIANI, F. R. A experiência latino-americana de integração e os novos acordos Brasil-Argentina-Uruguai. In: BAUMANN, Renato; LERDA, Juan Carlos (orgs.). Brasil-Argentina - Uruguai: a integração em debate. Brasília: Marco Zero, 1987.

VIGEVANI, Tullo; VEIGA, João Paulo. Mercosul: interesses e mobilização sindical. In: ZYLBERSTAJN, Hélio; RODRIGUES, Iram Jácome; CASTRO, Maria Silvia Portella; VIGEVANI, 
Tullo (orgs.). Processos de integração regional e a sociedade. O sindicalismo na Argentina, Brasil, México e Venezuela. São Paulo: Paz e Terra, 1996.

VILLA, Rafael Duarte. Política externa brasileira: capital social e discurso democrático na América do Sul. Revista Brasileira de Ciências Sociais, São Paulo, v. 21, n. 61, p. 60-89, jun. 2006. 